\title{
LETTER
}

\section{Orthopyroxene-magnetite symplectite in olivine gabbros from the lower crustal Oman Ophiolite: Oman Drilling Project, Hole GT2A}

\author{
Sayantani ChatTerJeE ${ }^{*}$, Debaditya BANDYOPAdHYAY ${ }^{* * * * *}$, Eiichi TAKAZAWA ${ }^{*}, \dagger$ \\ and Katsuyoshi MichIBAYASHI ${ }^{\ddagger}$ \\ *Department of Geology, Faculty of Science, Niigata University, Niigata 950-2181, Japan \\ ${ }^{* *}$ Department of Geology, University of North Bengal, Darjeeling 734013, India \\ ${ }^{* * *}$ Department of Geology, University of Calcutta, Kolkata 700019, India \\ $\dagger$ Japan Agency for Marine-earth Science and Technology, Yokosuka 237-0061, Japan \\ ${ }^{\ddagger}$ Graduate School of Environmental Studies, Nagoya University, Nagoya 464-8602, Japan
}

\begin{abstract}
Oxidation states within the planetary interior are intrinsically linked with the broad scale tectonism; however, it is difficult to estimate the actual oxidation conditions. Orthopyroxene-magnetite symplectite formed by olivine oxidation may provide a significant clue into such oxidation events. Here we report detailed mineralogical and petrological synthesis of such orthopyroxene-magnetite symplectites from olivine gabbros of Oman Ophiolite (Hole GT2A, ICDP Oman Drilling Project). In order to understand how oxidation affects different olivine compositions, we employed a phase equilibria approach and computed several temperature-composition diagrams at a fixed pressure $(1 \mathrm{kbar})$. Our experiments predict the coexistence of olivine with $\mathrm{Fo}_{75-76}$ and $\mathrm{Fo}_{71}$ with the orthopyroxene $\left(\mathrm{En}_{79}\right.$ and $\left.\mathrm{En}_{76}\right)$, respectively, which is remarkably similar to the mineral chemistry obtained from the Oman lower crustal gabbros. From the magnetite content, we also infer that the symplectite formation may have taken place over a range of temperatures $\left(600-1000^{\circ} \mathrm{C}\right)$ via subsolidus olivine oxidation and/or melt (oxidizing)-olivine interaction. The latter is more probable, considering the partial occurrence of orthopyroxene and clinopyroxene rim adjacent to the symplectites.
\end{abstract}

Keywords: Olivine gabbro, Orthopyroxene-magnetite symplectite, Oxidation, Lower crust, Oman Ophiolite

\section{INTRODUCTION}

Symplectites are vermicular intergrowths of two or more minerals and occur as coronas around a mineral or as reaction rim between two minerals (Mongkoltip and Ashworth, 1983; Obata, 2011 and references therein). Symplectites could be formed via different magmatic or metamorphic processes, which include igneous crystallization, melt-rock interaction, solid state transformation, fluid ingression, and oxidation and, thus, are frequently used as an important proxy to reconstruct physico-chemical conditions that rocks have undergone (e.g., Godard and

doi:10.2465/jmps.201130f

S. Chatterjee, sayantani.chatterjee89@gmail.com Corresponding author

D. Bandyopadhyay, debaditya.b2r@gmail.com Corresponding author
Martin, 2000). Several varieties of zoned corona with symplectites, dominantly consisting of orthopyroxene, magnetite, amphibole, and/or clinopyroxene, are excellent examples of such microstructure commonly reported from olivine-bearing gabbroic rocks or their metamorphic equivalents. These are usually interpreted to be formed at various stages of reaction between plagioclase and olivine ( \pm fluid) in retrograde or prograde metamorphism (e.g., Mongkoltip and Ashworth, 1983; Ashworth, 1986; Joesten, 1986; Ashworth and Birdi, 1990; Ashworth and Sheplev, 1997; De Haas et al., 2002; Lang et al., 2004; Gallien et al., 2012), as well as late stage cooling in a magmatic system (Griffin and Heier, 1973; Ambler and Ashley, 1977). Some monomineralic or symplectitic coronas around olivine (probably not involving reaction with plagioclase) are, however, interpreted to be produced at low pressures $(\leq 1-2 \mathrm{kbar})$ by reaction between melt 
(oxidized) and pre-existing olivine (Coombs and Gardner, 2004; Efimov and Malitch, 2012); crystallization of highly oxidized melt and/or subsolidus (or subliquidus) oxidation of pre-existing (normal) olivine phenocrysts (Cortés et al., 2006; Ichiyama et al., 2013). Here we report such orthopyroxene-magnetite symplectite within the lower crustal olivine gabbro of Hole GT2A from Oman Ophiolite, drilled during ICDP Oman Drilling Project (Oman DP) Phase I (foliated/layered gabbro transition), at Wadi Gideah in the Wadi Tayin massif. Lower crustal unit comprises almost two third parts of the Oman ophiolite; however, previous studies (Kelemen et al. 2020 and references therein) suggest that there is more to be explored about the formation mechanism of the unit. Here we attempt to shed some light on the symplectite formation in olivine gabbros (an important member of the lower crustal unit), especially in the context of oxidation, to understand the lower crustal accretion processes in a spreading axis.

\section{GEOLOGICAL SETTING AND SAMPLING}

Oman Ophiolite is the largest and best-aerial exposure of the obducted oceanic crust and upper mantle in the world. The southern part of Oman Ophiolite $\left(\sim 30000 \mathrm{~km}^{2}\right)$ consists of several massifs over $500 \mathrm{~km}$ long in a $\mathrm{NW}^{-} \mathrm{SE}$ direction along the coast of Oman. A target of the drilling in the site GT2A was to obtain the total section from the middle to upper part of foliated gabbros $(406.7 \mathrm{~m})$ (Fig. 1). Hole GT2A was drilled at Wadi Gideah in the Wadi Tayin massif (UTM: 40Q 655960.7E/2529193.5N). In

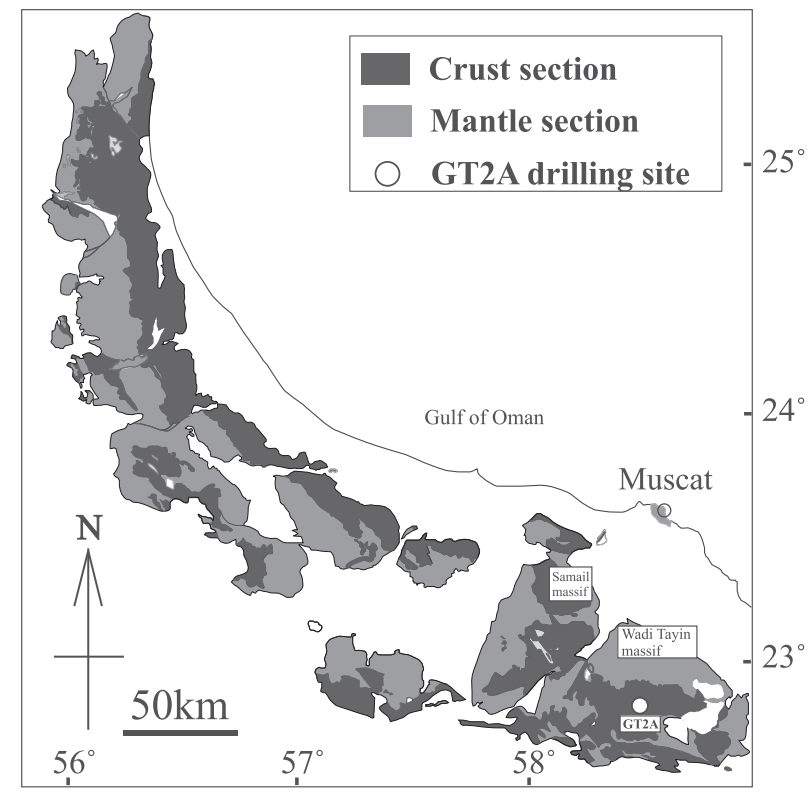

Figure 1. Simplified geological map of Oman Ophiolite, after Nicolas et al., (2000). The circle indicates the drill hole location of GT2A, Phase 1 of Oman Drilling Project. relatively flat wadis, the crustal section dips gently to the south and exposes shallower level to the south and deeper level to the north. The north-west trending foliated gabbro shows moderate dips to the southwest. The diffuse layering of foliated gabbro is parallel to the magmatic layering in the layered gabbro (Kelemen et al., 2020). The main rock types are olivine gabbros to gabbros with some veinlets of hornblende gabbros. The three most representative olivine gabbro samples, Hole GT2A$76 \mathrm{Z}-3,21-26 \mathrm{~cm}, 112 \mathrm{Z}-3,35-40 \mathrm{~cm}$, and 121Z-2, 2-7 $\mathrm{cm}$, have been taken from different depth ranges, 199.455, 303.361, and 323.502 m CCD (Chikyu curated depth in meter), respectively (Kelemen et al., 2020) for the study of oxidation and formation conditions.

\section{ANALYTICAL TECHNIQUE}

Polished thin sections were made for mineral chemical analysis. Each mineral in the three olivine gabbro samples (olivine, orthopyroxene, clinopyroxene, plagioclase, magnetite, and ilmenite) was analyzed by an electron probe microanalyzer with wavelength dispersive X-ray spectrometry (JEOL JXA-8600SX) at Niigata University, using an acceleration voltage of $15 \mathrm{kV}, 13 \mathrm{nA}$ beam current, and $\sim 1 \mu \mathrm{m}$ beam diameter. The following mineral standards were used: $\mathrm{Si}$ and $\mathrm{Ca}$, wollastonite $\left(\mathrm{CaSiO}_{3}\right)$; $\mathrm{Al}$, corundum $\left(\mathrm{Al}_{2} \mathrm{O}_{3}\right) ; \mathrm{Fe}$ and $\mathrm{Mn}$, manganese ferrite $\left(\mathrm{MnO}-\mathrm{Fe}_{2} \mathrm{O}_{3}\right) ; \mathrm{Ti}$, rutile $\left(\mathrm{TiO}_{2}\right) ; \mathrm{Mg}$, periclase $(\mathrm{MgO})$; $\mathrm{Cr}$, eskolaite $\left(\mathrm{Cr}_{2} \mathrm{O}_{3}\right)$; Na, jadeite $\left(\mathrm{NaAlSi}_{2} \mathrm{O}_{6}\right)$; $\mathrm{K}$, potassium titanium phosphate $\left(\mathrm{KTiOPO}_{4}\right)$; $\mathrm{Ni}$, nickel oxide $(\mathrm{NiO})$, and $\mathrm{Ba}$, barium titanate $\left(\mathrm{BaTiO}_{3}\right)$. Ferric iron was calculated based on the assumption of stoichiometry (Droop, 1987). In each case, a JEOL software was used for ZAF matrix correction. Acquisition of backscattered electron images was conducted using a JEOL JSMIT100BU scanning electron microscope with Oxford Aztec Energy Standard X-act energy dispersive spectrometer (SEM-EDS) at Niigata University.

\section{RESULTS}

The studied olivine gabbro samples are coarse- to medium-grained, with ophitic to poikilitic textures. They consist of $\sim 55-70$ vol $\%$ plagioclase, $\sim 15-25$ vol $\%$ clinopyroxene, $\sim 10-15$ vol $\%$ olivine, and a minor amount of orthopyroxene $(\leq 2 \mathrm{vol} \%)$ and oxide minerals (1-4 vol\%; mainly magnetite). Olivine is mostly subhedral, whereas clinopyroxene (without zoning or exsolution) shows subophitic relationship with plagioclase. Symplectite consists mainly of two mineral phases, orthopyroxene and magnetite. The width of homogeneous orthopyroxene grains ranges up to $300 \mu \mathrm{m}$ (Fig. 2). The width of vermic- 

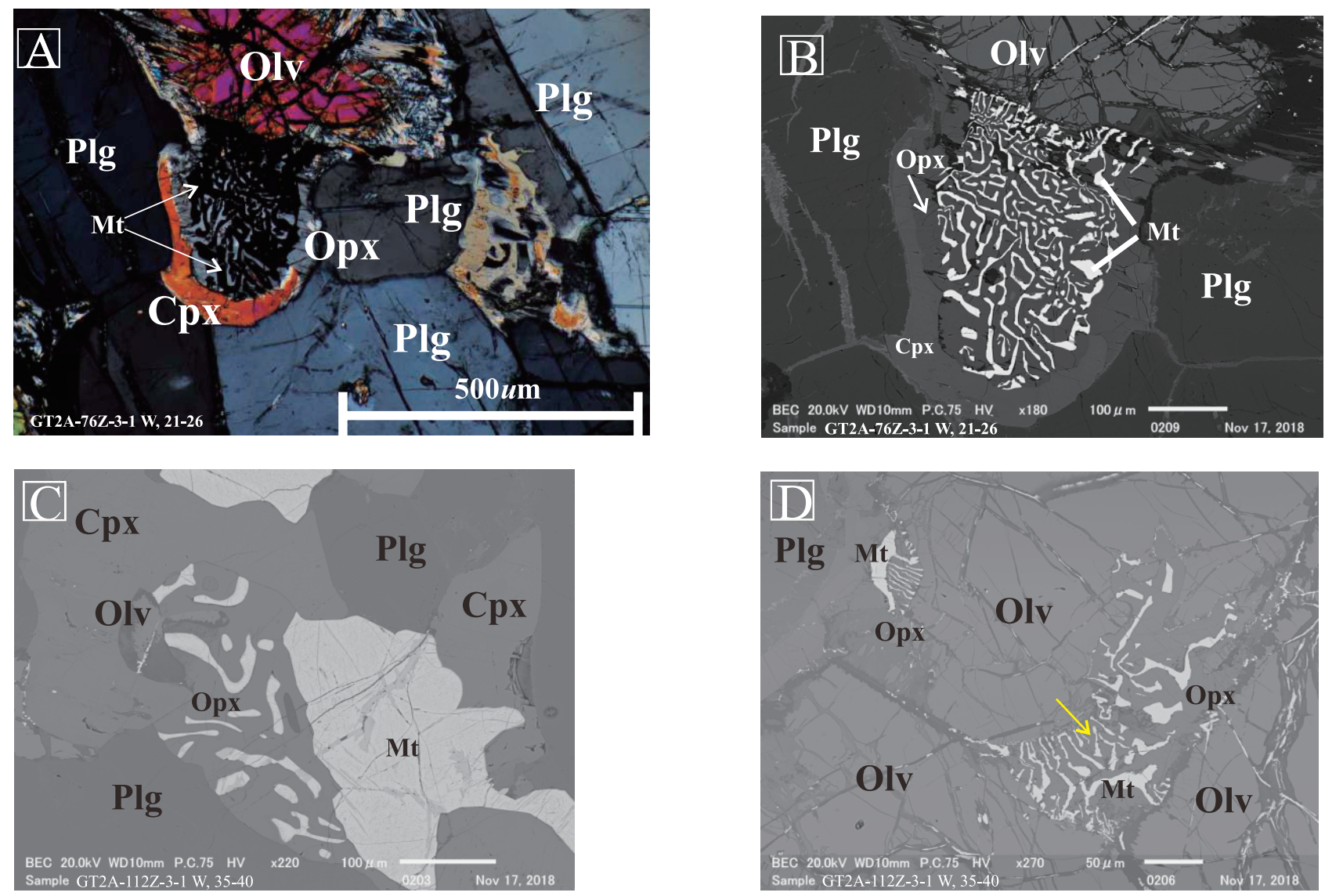

Figure 2. Photomicrographs of orthopyroxene-magnetite symplectite in olivine gabbro of Oman Ophiolite. (A) GT2A-76Z-3, 21-26 cm, general view under cross-polarized light. (B) GT2A-76Z-3, 21-26 cm, close-up backscattered image of (A). Olivine with symplectite and clinopyroxene rim. (C) GT2A-112Z-3, 35-40 cm, backscattered image. (D) GT2A-112Z-3, 35-40 cm, backscattered image. The area pointed with a yellow arrow indicates orthopyroxene + magnetite symplectite that only associated with olivine grains. Cpx, clinopyroxene; Mt, magnetite; Olv, olivine; Opx, orthopyroxene, Plg, plagioclase.

ular magnetite intergrowths within orthopyroxene ranges 20-30 $\mu \mathrm{m}$. Closer inspection revealed that the orthopyroxene + magnetite symplectite is only present adjacent to olivine (Fig. 2D). Such orthopyroxene-hosted magnetite lamellae usually occur as fine-grained rods having a perpendicular arrangement to the contact of the adjacent olivine and gradually grades away (from olivine) into more coarse-grained, irregular intergrowths (Figs. 2A and 2D). Texturally, the orthopyroxene-magnetite symplectite appears as replacement of olivine (Figs. 2C and 2D) and, in some rare occasion, is partly surrounded by clinopyroxene and orthopyroxene rims (Figs. 2A and 2B). The olivine forsterite content varies between $\mathrm{Fo}_{71-76}$ where the orthopyroxene composition $\left(\mathrm{En}_{76-78} \mathrm{Fs}_{19-22} \mathrm{Wo}_{1.5-1.8}\right)$ is characterized by relatively high $\mathrm{Mg} \#[=100 \times \mathrm{Mg} /(\mathrm{Mg}+$ $\mathrm{Fe}$ ) that varies between 75-79] and low Fe content (Supplementary Table S1; available online from https://doi. org/10.2465/jmps.201130f). The clinopyroxene in olivine gabbro is $\mathrm{En}_{45-46} \mathrm{Fs}_{8-9} \mathrm{Wo}_{42-47}$ with $\mathrm{Mg} \#$ varying between 76-80 (Table S1). Plagioclase anorthite content varies be- tween 73 and 77 (Table S1). Magnetite, chlorite, and serpentine are present within the cracks of olivine. In a few places, secondary orthopyroxene rims are present around olivine (other than symplectite). No substantial presence of plagioclase is noted with symplectite phase. Analyses of vermicules of magnetite within symplectite show that the $\mathrm{TiO}_{2}$ content between $1.0-8.0 \mathrm{wt} \%$ and the $\mathrm{FeO}$ content is restricted between $79-83 \mathrm{wt} \%$ (magnetite content varies between 70-92) (Table S1).

\section{DISCUSSION}

The textural characteristics and chemical compositions suggest that the orthopyroxene-magnetite intergrowth is a result of the replacement of olivine in lower crustal olivine gabbros in Oman Ophiolite. Our samples partially possess orthopyroxene and clinopyroxene rim, adjacent to the studied symplectite (Figs. 2A and 2B). It is important to highlight that such multilayered corona along with clinopyroxene + spinel and amphibole + spinel symplec- 
tite have been previously reported in the literature, and both magmatic and metamorphic processes were advocated (e.g., Joesten, 1986; De Haas et al., 2002; Gallien et al., 2012). Based on the sophisticated phase equilibria (with chemical potential relationship) modelling and detailed trace element analysis, Gallien et al. (2012) concluded that such complex reaction microstructure formed at 5-6.5 kbar and $<900{ }^{\circ} \mathrm{C}$ via diffusion-controlled solidstate reaction between olivine and plagioclase, coupled with peritectic reaction of olivine and interstitial liquid (forming orthopyroxene). Subsequent magmatic (crystallization of intercumulus liquid) and metamorphic transformations explain the formation of the amphibole rim and amphibole + spinel symplectite. In the present study, closer petrographic inspection reveals that such typical multilayered corona or reaction rim composed of clinopyroxene + spinel and/or amphibole + spinel symplectites are missing. Moreover, the only type of symplectites, i.e., orthopyroxene + magnetite symplectites, documented in the studied samples are systematically associated only with olivine, regardless of the presence of plagioclase (Fig. 2D). Owing to this observation, the possibility of olivine-plagioclase reaction is ruled out in our study. Moreover, olivine-plagioclase reaction usually takes place around 5-6.5 kbar (Gallien et al., 2012), whereas stratigraphic reconstruction suggests that the depth of the studied sample (GT2A) should not be more than $4 \mathrm{~km}$ (equivalent to $\sim 1$ kbar; Kelemen et al., 2020), confirming our textural interpretation. With these lines of evidence, we thus interpret that the discussed texture might be dominantly oxidation-induced. Oxidation of natural olivine has been classically defined by Goode (1974) as follows:

$$
\begin{gathered}
3 \mathrm{Mg}_{2} \mathrm{SiO}_{4} \text { (forsterite) }+3 \mathrm{Fe}_{2} \mathrm{SiO}_{4} \text { (fayalite) }+\mathrm{O}_{2} \\
=2 \mathrm{Fe}_{3} \mathrm{O}_{4} \text { (magnetite) }+6 \mathrm{MgSiO}_{3} \text { (enstatite) } .
\end{gathered}
$$

Goode (1974) also described that only for the olivine with $\mathrm{Fo}_{63-75}$, orthopyroxene-magnetite symplectites are expected to be the best developed, consistent with our olivine composition $\left(\mathrm{Fo}_{71} ; \mathrm{Fo}_{75-76}\right)$. In order to test the oxidation hypothesis for symplectite formation, we performed phase equilibria modelling using Perple_X software (Connolly, 2005, 2009) utilizing internally consistent thermodynamic data set of Holland and Powell (1998) [updated in 2002 with modification employed by Klemme et al., (2009) and Ziberna et al. (2013)]. To note the compositional changes of olivine, orthopyroxene, and spinel (in terms of magnetite content) during oxidation, we used ideal olivine composition for $\mathrm{Fo}_{50}$, $\mathrm{Fo}_{60}$, and $\mathrm{Fo}_{70}$ (Fig. 3) and subsequently reconstructed the olivine composition in a complete oxidized state with $X_{\mathrm{Fe}^{3+}}\left[\mathrm{Fe}^{3+} /\left(\mathrm{Fe}^{3+}+\mathrm{Fe}^{2+}\right)\right]=1$. We then computed $T$ (tem-
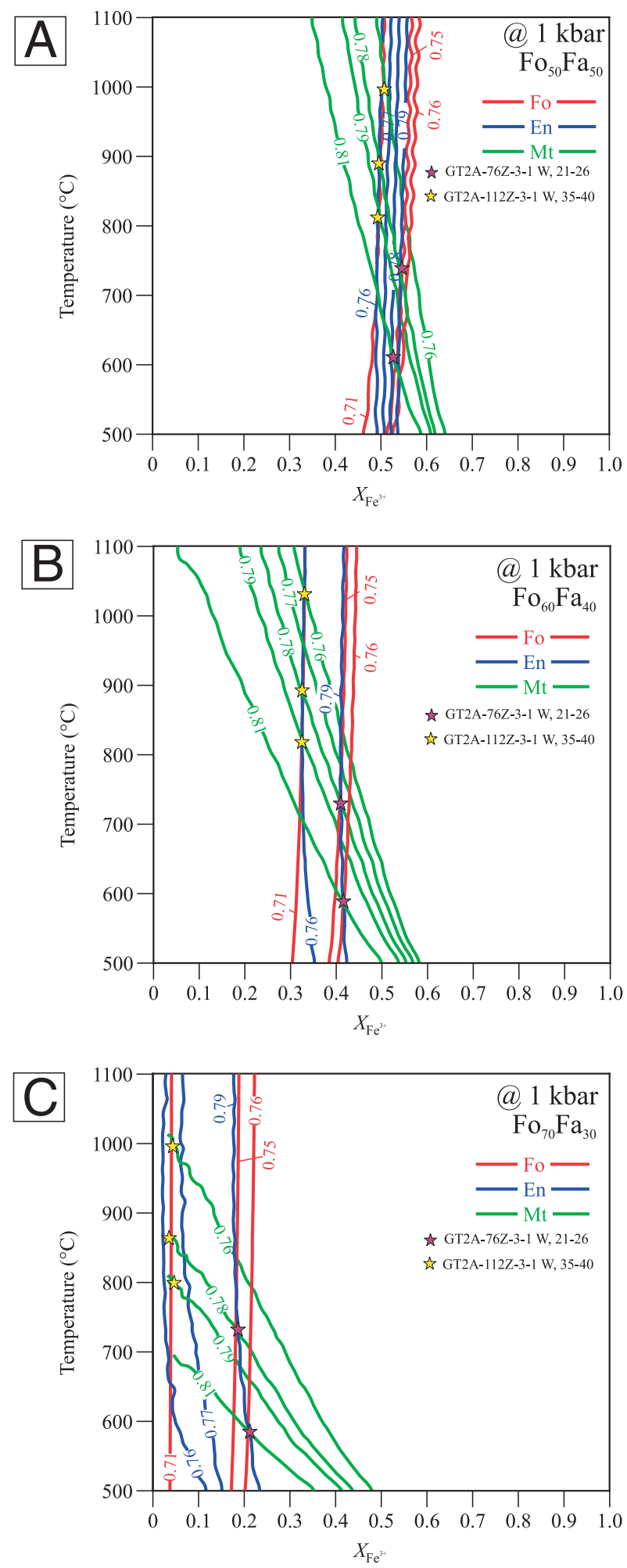

Figure 3. Compositional changes of olivine, orthopyroxene, and spinel (in terms of magnetite content) using (A) $\mathrm{Fo}_{50}$, (B) $\mathrm{Fo}_{60}$, and (C) $\mathrm{Fo}_{70}$ for olivine composition.

perature) $-X_{\mathrm{Fe}^{3+}}$ sections at a fixed pressure of $1 \mathrm{kbar}$ (Kelemen et al., 2020) in the $\mathrm{FeO}-\mathrm{MgO}-\mathrm{SiO}_{2}-\mathrm{O}_{2}$ (FMSO) system, using solution models of olivine (Hol- 
land and Powell, 1998), orthopyroxene (Powell and Holland, 1999), and spinel (Klemme et al., 2009). The results of the corresponding isopleths in $T-X_{\mathrm{Fe}^{3+}}$ sections are given in Figure 3 (for clarity, the detailed pseudosection has not been shown. The stable assemblage is orthopyroxene, spinel, and olivine). Irrespective of the olivine composition, our primary observation indicates that the forsterite content of the olivine will increase with increasing $\mathrm{O}_{2}$ content. This is exactly consistent with the suggestion of Haggerty and Baker (1967), who documented exsolution of hematite associated with more forsteritic olivine or formation of a magnetite and orthopyroxene symplectic intergrowth during high temperature oxidation of basaltic olivine. Accordingly, we should expect the presence of a low forsterite olivine precursor before oxidation, but it is difficult to infer it owing to homogeneous composition of the olivine. Irrespective of the olivine composition, we found that the $\mathrm{Fo}_{75-76}$ and $\mathrm{Fo}_{71}$ isopleths almost overlap with the $\mathrm{En}_{79}$ and $\mathrm{En}_{76}$, respectively, and that the effect of temperature is insensitive (Fig. 3). Thus, we can interpret that olivine with $\mathrm{Fo}_{75-76}$ and $\mathrm{Fo}_{71}$ can coexist with orthopyroxene with $\mathrm{En}_{79}$ and $\mathrm{En}_{76}$, respectively. Even considering the simpler FMSO system, we have obtained a remarkable match between the phase diagram analysis and obtained mineral chemistry supporting the oxidation hypothesis. Magnetite isopleths of the spinels crosscut forsterite and enstatite isopleths in different temperature ranges from 600 to 1000 ${ }^{\circ} \mathrm{C}$, suggesting the possibilities of subsolidus oxidation (of olivine) and/or interaction between oxidized melt and olivine. It is noteworthy to mention that the FMSO system does not adequately explain the $\mathrm{Al}$ and $\mathrm{Cr}$ (although relatively minor) contents within magnetite. However, their presence has been documented by Goode (1974), who hypothesized to be sourced from primary spinel inclusions within olivine or from adjacent plagioclase. Owing to the considered spinel solution model and the modelled FMSO system, our calculation can only predict magnetite and magnesio-ferrite components. Thus, we emphasize that the predicted result might not be exactly equivalent to the end-member calculated from mineral chemistry and might affect temperature estimation. The origin of the orthopyroxene rim adjacent to the symplectites (Fig. 2A) might be the peritectic rim; however, it could be the manifestation of different morphology of olivine oxidation (with changing forsterite content) or even melt-rock interaction. It is particularly difficult for us to ascertain the origin of the clinopyroxene rim. Coombs and Gardner (2004) documented the formation of amphibole and pyroxene rims around olivine during the $\mathrm{H}_{2} \mathrm{O}$-saturated low pressure (50 and $150 \mathrm{MPa}$ ) melt-rock experiment of forsteritic olivine in rhyolitic and rhyodacitic melts. We, therefore, speculate that such partial orthopyroxene and clinopyroxene rims might have been formed by melt-rock interaction in a relatively dry system, but further studies are required to have more comprehensive understandings.

\section{CONCLUSION}

We here report the occurrences of orthoyroxene-magnetite symplectite around olivine within lower crustal gabbros of Oman Ophiolite (Hole GT2A, ICDP Oman Drilling Project). Detailed petrographic analysis suggests that the symplectite is formed via oxidation of olivine instead of olivine-plagioclase reaction at relatively high-pressures. Detailed phase equilibria-based modeling supports this observation and predicts the coexistence of olivine with $\mathrm{Fo}_{75-76}$ and $\mathrm{Fo}_{71}$ with the orthopyroxene $\left(\mathrm{En}_{79}\right.$ and $\mathrm{En}_{76}$ ) that closely resembles the mineral chemistry of the Oman lower crustal gabbros. Magnetite content suggests that the texture evolved within $600-1000{ }^{\circ} \mathrm{C}$, indicating the possibility of subsolidus olivine oxidation and/or reaction with oxidizing melt. This work clearly demonstrates the potential of the oxidation-induced symplectite in deciphering the oxidation conditions of the lower oceanic crust and detailed oxybarometric analysis, which we consider as the scope of future work.

\section{ACKNOWLEDGMENTS}

We would like to thank two anonymous reviewers for their constructive comments. Editorial handling by Dr. Yuji Ichiyama is sincerely acknowledged. This study was supported by JSPS KAKENHI Grant Numbers JP16H02742 and JP20H02005 to E.T. and JP16H06347 to K.M. We are thankful to Peter Kelemen and Damon Teagle for their great leadership and scientific discussions in the OmanDP and to Jürg Matter and Jude Coggon for their great management of the OmanDP. This research used samples provided by the OmanDP, which was made possible through co-mingled funds from the ICDP (PIs: Kelemen, P.B., Matter, J.M., and Teagle, D.A.H.), the Sloan Foundation- DCO (Grant 2014-3-01, PI: Kelemen, P.B.), NSF (NSF-EAR-1516300, PI: Kelemen, P.B.), NASA Astrobiology Institute (NNA15BB02A, PI: Templeton, A.), DFG (KO 1723/21-1, PI: Koepke, J.), JSPS (16H02742, PI: T.E. and JP16H06347, PI: M.K.), ERC (Adv: No. 669972; PI: Jamveit, B.), and SNF (20FI21_ 163073, PI: Früh-Green, G.), JAMSTEC, TAMU-JRSO, and contributions from the Sultan Qaboos University, CNRS- the University of Montpellier, Columbia University of New York, and the University of Southampton. S.C. and D.B. contributed equally to this work. 


\section{SUPPLEMENTARY MATERIAL}

Supplementary Table S1 is available online from https:// doi.org/10.2465/jmps.201130f.

\section{REFERENCES}

Ambler, E.P. and Ashley, P.M. (1977) Vermicular orthopyroxenemagnetite symplectites from the Wateranga layered mafic intrusion, Queensland, Australia. Lithos, 10, 163-172.

Ashworth, J.R. (1986) The role of magmatic reaction, diffusion and annealing in the evolution of coronitic microstructure in troctolitic gabbro from Risor, Norway: a discussion. Mineralogical Magazine, 50, 469-473.

Ashworth, J.R. and Birdi, J.J. (1990) Diffusion modelling of coronas around olivine in an open system. Geochimica et Cosmochimica Acta, 54, 2389-2401.

Ashworth, J.R. and Sheplev, V.S. (1997) Diffusion modelling of metamorphic layered coronas with stability criterion and consideration of affinity. Geochimica et Cosmochimica Acta, 61, 3671-3689.

Connolly, J.A.D. (2005) Computation of phase equilibria by linear programming: A tool for geodynamic modeling and its application to subduction zone decarbonation. Earth and Planetary Science Letters, 236, 24-541.

Connolly, J.A.D. (2009) The geodynamic equation of state: What and how. Geochemistry. Geophysics, Geosystems, 10, 1-19.

Coombs, M.L. and Gardner, L. (2004) Reaction rim growth on olivine in silicic melts: Implications for magma mixing. American Mineralogist, 89, 48-758.

Cortés, J.A., Wilson, M., Condliffe, E. and Francalanci, L. (2006) The Occurrence of Forsterite and Highly Oxidizing Conditions in Basaltic Lavas from Stromboli Volcano, Italy. Journal of Petrology, 47, 1345-1373.

De Haas, G.L.M., Nijland, T.G., Valbracht, P.J., Maijer, C., et al. (2002) Magmatic versus meta- morphic origin of olivine-plagioclase coronas. Contributions to Mineralogy and Petrology, 143, 537-550.

Droop, G.T.R. (1987) A general equation for estimating Fe3+ concentrations in ferromag- nesian silicates and oxides from microprobe analyses, using stoichiometric criteria. Mineralogical Magazine, 51, 431-435.

Efimov, A.A. and Malitch, K.N. (2012) Magnetite-Orthopyroxene Symplectites in Gabbros of the Urals: A Structural Track of Olivine Oxidation. Geology of Ore Deposits, 54, 531-539.

Gallien, F., Mogessie, A., Hauzenberger, C.A., Bjerg, E., et al. (2012) On the origin of multi-layer coronas between olivine and plagioclase at the gabbro-granulite transition, Valle FertilLa Huerta Ranges, San Juan Province, Argentina. Journal of Metamorphic Geology, 30, 281-301.

Godard, G. and Martin, S. (2000) Petrogenesis of kelyphites in garnet peridotites: a case study from the Ulten zone, Italian Alps. Journal of Geodynamics, 30, 17-145.

Goode, A. (1974) Oxidation of natural olivines. Nature, 248, 500501
Griffin, W.L. and Heier, K.S. (1973) Petrological implications of some corona structure. Lithos, 6, 315-335.

Haggerty, S.E. and Baker, I. (1967) The Alteration of Olivine in Basaltic and Associated Lavas. Contributions to Mineralogy and Petrology, 16, 233-257.

Holland, T.J.B. and Powell, R. (1998) An internally consistent thermodynamic data set for phases of petrological interest. Journal of Metamorphic Geology, 16, 309-343.

Ichiyama, Y., Morishita, T., Tamura, A. and Arai, S. (2013) Petrology of peridotite xenolith-bearing basaltic to andesitic lavas from the Shiribeshi Seamount, off northwestern Hokkaido, the Sea of Japan. Journal of Asian Earth Sciences, 76, 48-58.

Joesten, R. (1986) The role of magmatic reaction, diffusion and annealing in the evolution of coronitic microstructure in troctolitic gabbro from Risor, Norway. Mineralogical Magazine, $50,441-67$.

Kelemen, P.B., Matter, J.M., Teagle, D.A.H., Coggon, J.A. and the Oman Drilling Project Science Team (2020) Site GT2: foliated to layered gabbro transition. Proceedings of the Oman Drilling Project: College Station, TX (International Ocean Discovery Program).

Klemme, S., Ivanic, T.J., Connolly, J.A.D. and Harte, B. (2009) Thermodynamic modelling of Cr-bearing garnets with implications for diamond inclusions and peridotite xenoliths. Lithos, 112, 986-991.

Lang, H.M., Wachter, A.J., Peterson, V.L. and Ryan, J.G. (2004) Coexisting clinopyroxene / spinel and amphibole / spinel sym- plectites in metatroctolites from the Buck Creek ultramafic body, North Carolina Blue Ridge. American Mineralogist, $80,20-30$.

Mongkoltip, P. and Ashworth, J.R. (1983) Quantitative Estimation of an Open-system Symplectite-forming Reaction: Restricted Diffusion of $\mathrm{Al}$ and $\mathrm{Si}$ in Coronas around Olivine. Journal of Petrology, 24, 635-61.

Nicolas, A., Boudier, F., Ildefonse, B. and Ball, E. (2000) Accretion of Oman and United Arab Emirates ophiolite-Discussion of a new structural map. Marine Geophysical Researches, 21, 147-180.

Obata, M. (2011) Kelyphite and symplectite: textural and mineralogical diversities and universality, and a new dynamic view of their structural formation. New Frontiers in Tectonic Research-General Problems. Sedimentary Basins and Island Arcs, 93-122.

Powell, R. and Holland, T. (1999) Relating formulations of the thermodynamics of mineral solid solutions: activity modeling of pyroxenes, amphiboles, and micas. American Mineralogist, $84,1-14$.

Ziberna, L., Klemme, S. and Nimis, P. (2013) Garnet and spinel in fertile and depleted mantle: insights from thermodynamic modelling. Contributions to Mineralogy and Petrology, 166, 411-421.

Manuscript received November 30, 2020

Manuscript accepted April 21, 2021

Manuscript handled by Yuji Ichiyama 